\title{
Nodular Pulmonary Sarcoidosis Mimicking Disseminated Malignant Disease
}

\author{
Luka Filipović-Grčić ${ }^{1}$ (D), Neva Coce ${ }^{1}$, David Žižić ${ }^{1}$, Silvana Giljanović Jacmenović ${ }^{1}$ \\ ${ }^{1}$ Department of Radiology, University Hospital Centre Zagreb, Zagreb, Croatia
}

OPEN ACCESS

Correspondence:

Luka Filipović-Grčić MD luka.filipovicg@outlook.com orcid.orcid.org/0000-0003-0024-8359

This article was submitted to RAD CASA Medical Sciences as the case report

Conflict of Interest Statement: The authors declare that the research was conducted in the absence of any commercial or financial relationships that could be construed as a potential conflict of interest.

Received: 6 May 2020 Accepted: 24 June 2020 Published: 22 July 2020

Citation:

Filipovic-Grcic L, Coce N, Žižić D and Giljanović-Jacmenović S. Nodular pulmonary sarcoidosis mimicking disseminated malignant disease.

RAD CASA - Medical Sciences. $543=50-51(2020): 71-74$ DOI: https://dx.doi.org/10.21857/ yvjrdclrdy

Copyright (C) 2020 Filipovic-Grcic L, Coce N, Zižić D and Giljanović-Jacmenović S. This is an open-access menovic $S$. This is an open-access af the Creative Commons Attribution of the Creative Commons Attribution License (CC BY). The use, distribution or reproduction in other forums is permitted, provided the original author(s) and the copyright owners(s) are credited and that the original publication in this journal is cited, in accordance

whit accepted adacemic practice. No

use, distribution or reproduction is permitted which does not comply with

\section{ABSTRACT:}

Due to its varying and often mimicking appearance, sarcoidosis is considered one of the great imitators in medicine.

A rare form of pulmonary sarcoidosis, the nodular form, can be mistaken for disseminated malignancy. We present the case of 38-year-old patient, whose chest $\mathrm{x}$ ray demonstrated a large number of pulmonary nodules, more than $1 \mathrm{~cm}$ in diameter, predominantly in a peripheral distribution, with bilaterally enlarged hila, thus making disseminated malignant disease a part of differential diagnosis.

The sight of multiple lung nodules can be very suggestive for metastatic disease and misleading in everyday clinical practice.

KeYwORDS: Sarcoidosis, Mimicking, Malignant disease, Nodules, Radiology; Nodular pulmonary sarcoidosis

\section{SAŽETAK:}

NODULARNA PLUĆNA SARKOIDOZA PRIKAZANA KAO IMITACIJA DISEMINIRANE MALIGNE BOLESTI Zbog svoje raznolike prezentacije i brojnih sličnosti s drugim bolestima, sarkoidoza je znana kao veliki imitator u medicini. Jedan od oblika sarkoidoze, nodularna plućna sarkoidoza, lako se može zamijeniti s malignom diseminiranom bolešću. Prikazujemo slučaj 38-godišnjeg pacijenta, čiji je torakalni rendgenogram pokazao veći broj periferno smještenih plućnih nodusa promjera većih od 1 $\mathrm{cm}$ uz obostrano uvećane hiluse. Takav nalaz upućivao je na diseminiranu malign bolest kao jednu od diferencijalnih dijagnoza. Cilj ovog prikaza slučaja je podsjetiti kolege na nodularnu plućnu sarkoidozu kao jednu od mogućih dijagnoza u slučaju ovako sugestivnih nalaza kod pacijenata bez ranije poznate maligne bolesti.

KLJUČnE RIJEČI: Sarkoidoza, Oponašanje, Maligna bolest, Noduli, Radiologija, Nodularna plućna sarkoidoza 


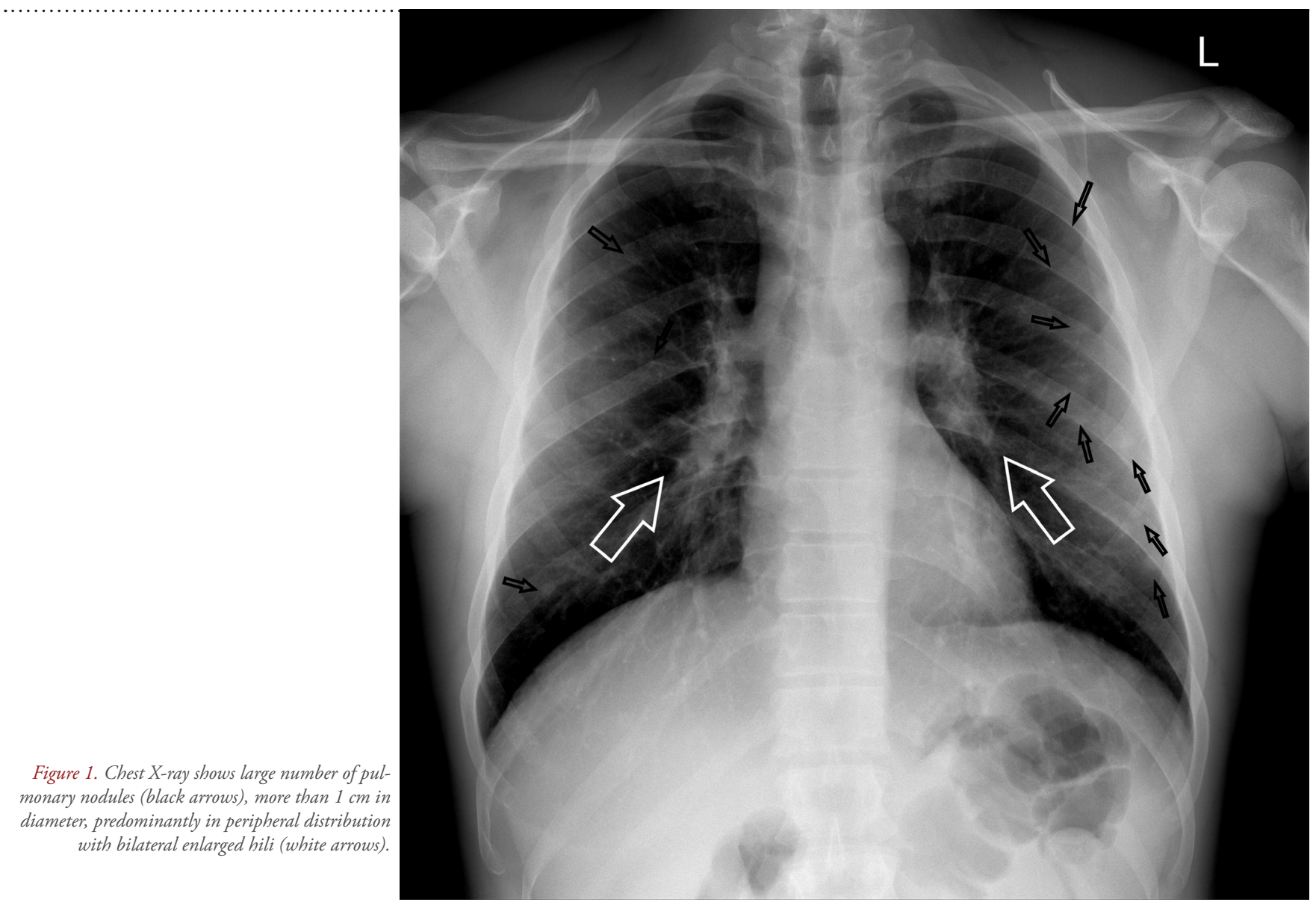

\section{INTRODUCTION}

Sarcoidosis is an idiopathic granulomatous disease which affects younger adults of all races, more commonly females, and those from northern Europe and Africa and the estimates of its prevalence in Europe ranges from 1 to 64 per 100000 persons $^{1}$ A considerable number of different organs and organ systems may be involved, the lungs being on the top of the list with $90 \%$ of the cases.

Diagnosis of sarcoidosis requires 3 elements: (a) radiographic and clinical findings consistent with sarcoidosis, (b) exclusion of diseases that present similarly, and (c) biopsy of the most accessible lesion, demonstrating noncaseating granulomas on histopathology².

When it comes to imaging, pulmonary sarcoidosis is best recognized for its typical presentation of mediastinal lymphadenopathy, occurring in $95 \%$ of the patients. ${ }^{3}$

Atypical radiographic presentation of pulmonary sarcoidosis varies, however, from alveolar opacities in alveolar sarcoidosis to distinct lung nodules in nodular form.

The nodular form is the rarest form of pulmonary sarcoidosis and has an estimated prevalence of 2,4-4 \% $0^{4,5}$. In most patients with nodular pulmonary sarcoidosis (NPS), radiographic imaging shows bilateral nodules measuring $1-7 \mathrm{~cm}$ in diameter and mediastinal lymphadenopathy ${ }^{4,5,6}$. However, NPS can display a whole array of other radiographic features apart from the above mentioned, such as pleural effusion, solitary mass, air bronchogram, cavitation, and pleural based masses. Knowing the radiographic appearance of NPS is important, since this may well be the only sign of the disease, as extrapulmonary involvement is not always present. ${ }^{7,8}$

One should also keep in mind that the NPS is not the only benign condition which can mimic metastasis of the lung. Various other benign diseases can present as multiple lung nodules as well, including infections, other granulomatous diseases and A-V malformations, amongst others? .

\section{CASE REPORT}

A 38-year-old male Caucasian presented to his GP with two erythematous macules of the forehead which erupted suddenly 3 months ago. He has a 20 pack-year history of cigarette smoking and an inconspicuous family history. He underwent tonsillectomy in the childhood and nasal septum operation 7 years ago. He has been suffering from asthma for 8 years, and is treated with Seretide Diskus $50 \mathrm{mcg} / 100 \mathrm{mcg}$ - 1 breath as needed, with poor therapy compliance.

At the time of his visit to GP he reported no difficulties with breathing, no cough, no fever, and routine blood tests were within normal ranges.

He was referred to a dermatologist who scheduled him for a skin biopsy of the lesions on the forehead.

Subsequent skin biopsy report described noncaseating granulomas and the dermatologist advised a chest $\mathrm{x}$ ray suspecting sarcoidosis.

Chest $\mathrm{x}$ ray (Figure 1) demonstrated a large number of pulmonary nodules, more than $1 \mathrm{~cm}$ in diameter, predominantly in peripheral distribution with bilateral enlarged hila, and the radiology report included lung metastases with hilar adenopathy in the differential diagnosis.

Considering the described bihilar lymphadenopathy pulmonologist insisted on skin and lung sarcoidosis as primary diagnosis and ordered additional laboratory and lung function tests. The test results were all within the reference values: $\mathrm{RBC}=5.17[\mathrm{x}$ $1012 / \mathrm{L}], \mathrm{Hb}=149$ [g/L], HCT=0.439 [L/L], MCV=84.9 [fL], $\mathrm{MCH}=28.8$ [pg], $\mathrm{MCHC}=339[\mathrm{~g} / \mathrm{L}], \mathrm{RDW}=13.0$ 


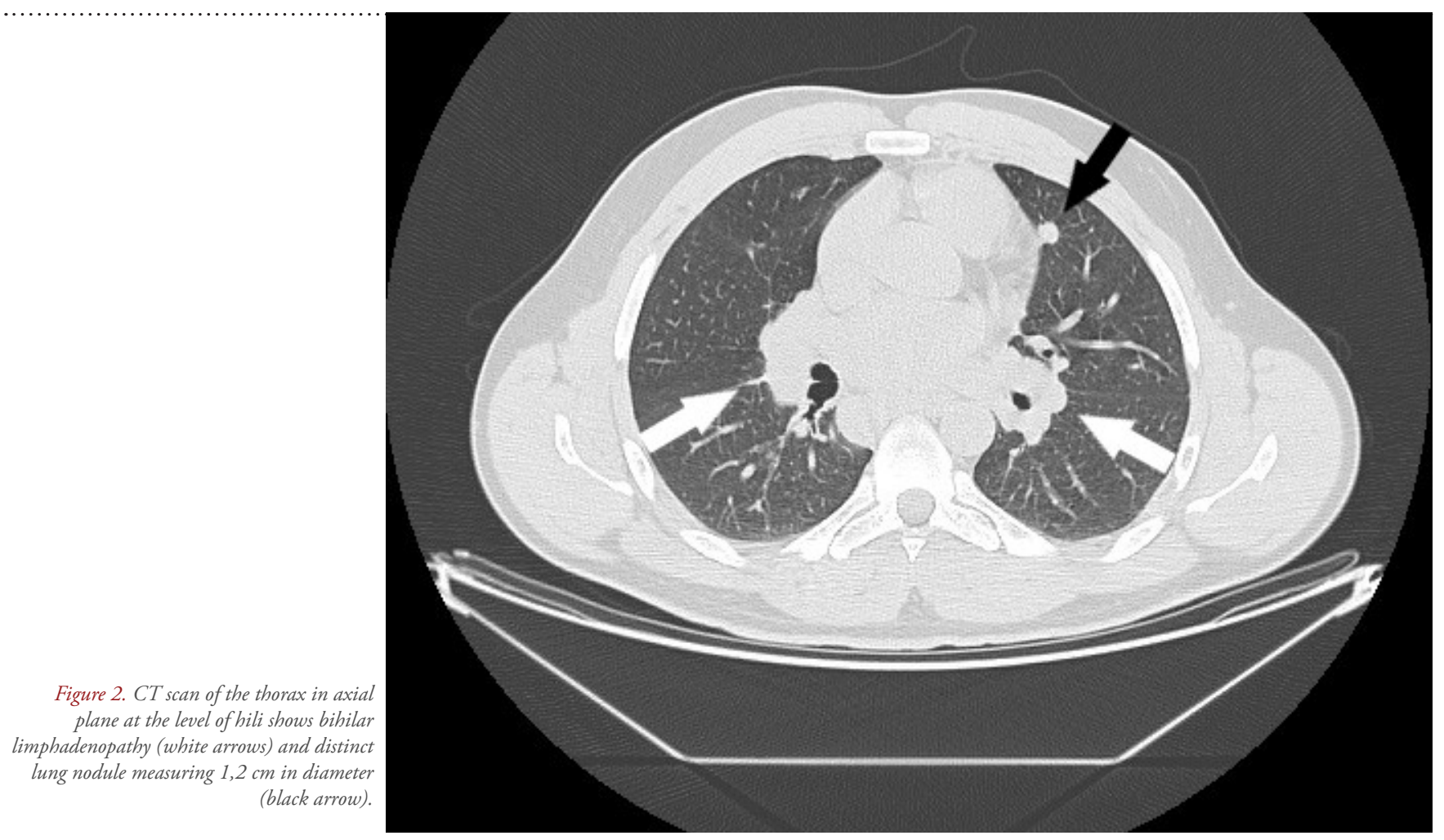

[\%], R-Ebl $\#=0.0[\mathrm{x} 109 / \mathrm{L}], \mathrm{R}-\mathrm{Ebl} \%=0$ [/100 Lkc], TLC $=5.0$ $[\mathrm{x} 109 / \mathrm{L}], \mathrm{EOS} \%=7.3,[\%], \mathrm{BASO} \%=0.8[\%], \mathrm{NE} \%=61.4[\%]$, $\mathrm{LYM} \%=17.6[\%], \mathrm{MONO} \%=12.9[\%], \mathrm{EOS} \#=0.37[\mathrm{x} 109 / \mathrm{L}]$, BASO\#=0.04 [x109/L], ANC=3.07 [x109/L], LYM\#=0.88 $[\mathrm{x} 109 / \mathrm{L}], \mathrm{MONO \#}=0.65[\mathrm{x} 109 / \mathrm{L}], \mathrm{PLT}=219[\mathrm{x} 109 / \mathrm{L}]$, $\mathrm{MPV}=10.7$ [fL], GLU=4.3 [mmol/L], T-Bil=12 [umol/L], Urea $=7.5[\mathrm{mmol} / \mathrm{L}], \mathrm{CR}=127[\mathrm{umol} / \mathrm{L}], \mathrm{ALP}=86[\mathrm{U} / \mathrm{L}]$, $\mathrm{ALT}=28[\mathrm{U} / \mathrm{L}], \mathrm{GGT}=19[\mathrm{U} / \mathrm{L}], \mathrm{LDH}=225[\mathrm{U} / \mathrm{L}], \mathrm{Ca}=2.28$ $[\mathrm{mmol} / \mathrm{L}], \mathrm{P} 04=0.87[\mathrm{mmol} / \mathrm{L}], \mathrm{CRP}=1.9[\mathrm{mg} / \mathrm{L}], \mathrm{GF}-$ $\mathrm{CKD}=62[\mathrm{~mL} / \mathrm{min} / 1,73 \mathrm{~m} 2], \mathrm{ACE}=71[\mathrm{U} / \mathrm{L}]$, Ca-portion=6.64 $[\mathrm{mmol} / \mathrm{L}]$, Pportion=47.15 [mmol/L]; Urine Sp. Weight $=1.027$ $[\mathrm{kg} / \mathrm{L}], \mathrm{PH}=5.0, \mathrm{Lkc}=0$, Nitrites=0, Prot=+, GLC=NORM, Ketones $=0, \mathrm{UBG}=\mathrm{NORM}, \mathrm{BIL}=0, \mathrm{Blood}=0, \mathrm{Erc}=0-2, \mathrm{Lkc}=0-2$, Transitional epithelium cells=0-1, Mucus=+, Hyaline cylinders $=2-4$

The results of ensuing lung function tests were also within normal range: FVC $100 \%$ (5,46 L), FEV1 98\% (4,39 L), Tiff. 0,8, MEF 50 90\%; DLCO 87\% , Kco 102\%, VA 87\%.

Additional CT scan of the thorax (Figure 2) demonstrated multiple, well defined lung nodules up to $1,2 \mathrm{~cm}$ in diameter, again predominantly in a peripheral distribution with bilateral hilar and mediastinal lymphadenopathy. In all lung lobes no micronodules were detected in perilymphatic distribution. Clearly defined nodules were interpreted as granulomas consistent with nodular form of lung sarcoidosis.

The pumonologist confirmed the diagnosis and decided there was no need for bronchoscopy with bronchoalveolar lavage as well as mediastinal biopsy.

The patient started to experience pains in joints, which led the pumonologist to prescribe $30 \mathrm{mg}$ of prednisone and replaced Seretide with Symbicort for asthma.

The pain in the joints ceased after few days and control $x$ ray preformed after 4 months revealed the reduction of number and size of bilateral nodules and discrete reduction of bihilar lymphadenopathy.

\section{Discussion}

True pulmonary metastases that spread from primary solid organ tumors may vary in size and location, often favouring lung bases and the subpleural space. Although generally well defined, their borders can also be ill defined, and they can contain cavitations caused by bleeding and necrosis?

Sarcoidosis is a systemic granulomatous disease, which, like the rest of granulomatous diseases, may present itself with a cluster of granulomas in the lungs, as well as in other organs. Clearly defined nodules in organ's tissue can mimic disseminated malignancy. ${ }^{10,11}$ Apart from nodular form of sarcoidosis, there are other granulomatous diseases that may lead to multiple nodules in the lungs, giving the impression of lung metastases, such as histoplasmosis and pulmonary hyalinizing granuloma ${ }^{12,13}$. Adding to the confusion, a number of other diseases can produce multiple pulmonary nodules, including pneumoconiosis, infectious (such as disseminated tuberculosis, invasive aspergillosis, chickenpox and measles), noninfectious inflammatory diseases (rheumatoid nodules, Wegener's granulomatosis), arteriovenous malformations, amyloid and infarcts ${ }^{11}$. These conditions should therefore also spring to mind when considering the right diagnosis.

\section{CONCLUSION}

Although the majority of sarcoidosis cases have a typical radiographic presentation involving hilar and mediastinal lymphadenopathy, with or without interstitial lesions in perilymphatic distribution, a small number of cases can be presented with distinct large parenchymal nodules, measuring from $1-7 \mathrm{~cm}$ in diameter, thus mimicking metastatic disease. It is therefore advisable to bear that in mind and include nodular form of pulmonary sarcoidosis as well as other possible benign conditions in differential diagnosis every time one sees large number of pulmonary nodules in a patient with not known primary malignancy. 


\section{LITERATURE:}

1 Criado E, Sánchez M, Ramírez J, et al., Pulmonary Sarcoidosis: Typical and Atypical Manifestations at High- Resolution CT with Pathologic Correlation; RadioGraphics 2010; 30:1567-1586 • Published online https://doi.org/10.1148/rg.306105512

2 Hunninghake GW, Costabel U, Ando M, et al. Statement on sarcoidosis. Joint statement of the American Thoracic Society (ATS), the European Respiratory Society (ERS) and the World Association of Sarcoidosis and Other Granulomatous Disorders (WASOG) adopted by the ATS Board of Directors and by the ERS Executive Committee, February 1999. Am J Respir Crit Care Med. 1999;160:736-755. https:// doi.org/10.1164/ajrccm.160.2.ats4-99

3 Reich JM. Mortality of intrathoracic sarcoidosis in referral vs population-based settings: influence of stage, ethnicity, and corticosteroid therapy. Chest2002;121(1):32-39. https://doi.org/10.1378/chest.121.1.32 4 Shahzad H, Ur-Rehman S, Fatima K, Sharif N, Bin Sarwar Zubairi A. Case series and literature review of multiple nodular sarcoidosis. BMC Research Notes. 2013 6:394. https://doi.org/10.1186/1756-0500-6-394 5 McCord MC, Hyman HL. Pulmonary sarcoidosis with the roentgenologic appearances of metastatic neoplasm; a report of two cases. Am J Roentgenol Radium Ther Nucl Med. 1952; 67(2):259-262

6 Naidich DP, Srichai MB, Krinsky GA. Computed Tomography and Magnetic Resonance of the Thorax. Lippincott Williams \& Wilkins; 2007. http://dx.doi.org/10.1594/ecr2017/C-0522

7 Sweidan AJ, Singh NK, Stein A, Tanios M, Nodular Sarcoidosis Mas- querading as Cancer, Clinical Medicine Insights: Circulatory, Respiratory and Pulmonary Medicine Volume 11: 1-3 @ The Author(s) 2017. https://doi.org/10.1177/1179548417703123

8 Malaisamy S, Dalal B, Bimenyuy C, Soubani AO: The clinical and radiologic features of nodular pulmonary sarcoidosis. Lung 2009, 187(1):9-15. https://doi.org/10.1007/s00408-008-9118-2 9 Mandel J, Stark PS. Differential diagnosis and evaluation of multiple pulmonary nodules. In: UpToDate in Pulmonary and Critical Care Medicine [CD-ROM]. Wellesley (MA): UpToDate, Inc; 2000-2004. 10 Koyama M, Terauchi T, Koizumi M, Gomi N, Kanda H. Skeletal Sarcoidosis Mimicking Metastatic Ovarian Cancer- A Case with FDGPET/CT. Remed Open Access. 2017; 2: 1078

11 Hammen I, ShersonDL, Davidsen JR, Systemic sarcoidosis mimicking malignant metastatic disease; European Clinical Respiratory Journal 2015, 2: 26761 https://doi.org/10.3402/ecrj.v2.26761

12 Dall Bello AG, Severo CB, Guazzelli LS, Oliveira FM, Hochhegger B, Severo LC. Histoplasmosis mimicking primary lung cancer or pulmonary metastases, J Bras Pneumol. 2013;39(1):63-68 http://dx.doi. org/10.1590/S1806-37132013000100009

13 Düzgün N, Kurtipek E, Esme H, Karanis MIE, Tolu E, Pulmonary Hyalinizing Granuloma Mimicking Metastatic Lung Cancer, Hindawi Publishing Corporation, Case Reports in Pulmonology, Volume 2015, Article ID 610417, 3 pages http://dx.doi.org/10.1155/2015/610417 